
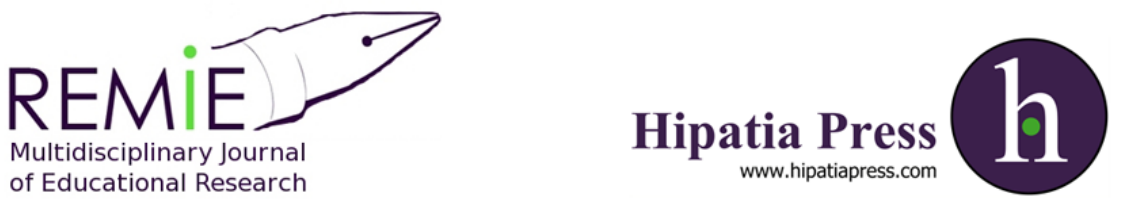

Instructions for authors, subscriptions and further details:

http://remie.hipatiapress.com

\title{
Multiple Victimization (Bullying and Cyberbullying) in Primary Education in Spain from a Gender Perspective
}

Rocío Jiménez ${ }^{1}$

1) Universidad de Sevilla

Date of publication: June $15^{\text {th }}, 2019$

Edition period: February 2019-June 2019

To cite this article: Jiménez, R. (2019). Multiple Victimization (Bullying and Cyberbullying) in Primary Education in Spain from a Gender Perspective. Multidisciplinary Journal of Educational Research, 9(2), 169-192. doi: 10.4471/remie.2019.4272

To link this article: http://dx.doi.org/10.447/remie.2019.4272

\section{PLEASE SCROLL DOWN FOR ARTICLE}

The terms and conditions of use are related to the Open Journal System and to Creative Commons Attribution License (CC-BY). 


\section{Multiple Victimization (Bullying and Cyberbullying) in Primary Education in Spain from a Gender Perspective}

Rocío Jiménez

Universidad de Sevilla

\section{Abstract}

Studies show that face-to-face aggression extends to other types of bullying behaviours through digital technologies. Current research is limited in primary education and contradictory in terms of gender. This study looked at the prevalence of bullying and cyberbullying in Spain at an early age, identifying groups of victims from a gender perspective. It also associated school variables (sense of belonging at school, absenteeism or student confidence in STEM subjects) to the most vulnerable profile. In a second analysis, 4756 Spanish 4th grade Primary Education pupils completed the TIMMS 2015 standardized survey. The results showed four groups of victims, two characterized by multiple victimization (bullying and cyberbullying). There were significant gender differences between the groups. The percentage of girls in the profile of victims of severe harassment was higher. However, overall there was a greater presence of boys across the different groups of victims. The school variables considered were associated differentially according to gender. The student sense of belonging at school was not the same for girls and boys, nor did they have the same attitude towards absenteeism. The results are discussed in relation to other studies together with conclusions regarding the design of educational interventions and future research.

Keywords: bullying perpetration, cyberbullying, gender studies, primary education, school curriculum, violence 
No. 2 June 2019, pp. 169-193

\title{
Victimización Múltiple (Bullying y ciberacoso) en la Educación
} Primaria en España desde una Perspectiva de Género

\author{
Rocío Jiménez \\ Universidad de Sevilla
}

\section{Resumen}

Los estudios demuestran que la agresión cara a cara se extiende a otros tipos de comportamientos de acoso escolar a través de tecnologías digitales. La investigación actual es limitada en educación primaria y contradictoria en términos de género. Este estudio analizó la prevalencia del bullying y el ciberacoso en España a una edad temprana, identificando grupos de víctimas desde una perspectiva de género. También asoció las variables escolares (sentido de pertenencia a la escuela, absentismo o confianza del estudiantado en las materias STEM) a perfiles más vulnerable. En un segundo análisis, 4756 alumnos españoles de educación primaria de cuarto grado completaron la encuesta estandarizada TIMMS 2015. Los resultados mostraron cuatro grupos de víctimas, dos caracterizadas por la victimización múltiple (bullying y cyberbullying). Hubo diferencias significativas de género entre los grupos. El porcentaje de niñas en el perfil de víctimas de acoso severo fue mayor. Sin embargo, en general, hubo una mayor presencia de niños en los diferentes grupos de víctimas. Las variables escolares consideradas se asociaron de forma diferencial según el género. El sentido de pertenencia del estudiantado en la escuela no era el mismo para niñas y niños, ni tenían la misma actitud hacia el absentismo. Los resultados se discuten en relación con otros estudios, junto con conclusiones sobre el diseño de intervenciones educativas y futuras investigaciones.

Keywords: acoso escolar, cyberbullying, estudios de género, educación primaria, currículo escolar, violencia

2013 Hipatia Press

ISSN: 2014-4272

DOI: $10.4471 /$ remie. 2019.4272 


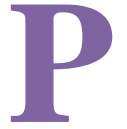

Peer harassment is a problem which has always been associated to school. However, widespread use of smartphones and tablets with internet connections at an increasingly earlier age has led to new forms of aggression which go beyond these confines via their use of digital technologies, in what the literature refers to as cyberbullying (Hinduja \& Patchin, 2013; Machimbarrena \& Garaigordobil, 2017).

School harassment or bullying implies consciously doing harm or being cruel to victims. In general, traditional forms of school bullying can be divided into three categories of aggression: physical (hit, kick), verbal (insults, teasing) and social (ignoring and isolating). Behind these behaviours lies an inequality of power (physical, verbal, psychological or social) between a weak victim and a strong aggressor leaving the victim defenceless (Garaigordobil, Martínez \& Machimbarrena, 2017).

Cyberharassment or cyberbullying is understood as a succession of intimidatory practices performed using digital technologies and which do harm to the victim. These practices include smears, threats and identity theft, amongst others. However, there is still no exact standard definition of cyberbullying (Maquilón, Giménez, Hernández \& García, 2011). This represents one of the most questionable aspects of research in this area because of its possible relation to inconsistent results regarding prevalence. Findings over the prevalence of cyberbullying vary widely and depend also on the samples and even how it is measured (Ockerman, Kramer \& Bruno, 2014; Vivolo-Kantor, Martell, Holland \& Westby, 2014).

Both face-to-face school bullying and its digital equivalent involve varied forms of inter-peer aggression and when they combine, they subject victims to multiple forms of harassment. For Ortega et al. (2012) the current categorization, traditional bullying as opposed to cyberbullying, is incapable of reflecting the complexity of these phenomena. Some specific types of cyberbullying may be similar to some specific types of traditional bullying. Studies on bullying and cyberbullying approach intimidation behaviours amongst peers as a continuum which oscillates between face-to-face aggression and smearing using digital technologies. Large studies, such as that by Olweus (2013), suggest that roughly $90 \%$ of cybervictims also suffer traditional bullying. The study by Hinduja \& Patching (2008) links cyberbullying and traditional bullying in the school playground. Youngsters 
intimidated at school are much more likely to be cyberbullied. Face-to-face aggression extends to other types of cyberbullying behaviours. Hence these types of behaviours often lead to continued aggression. Some studies (Del Rey, Elipe \& Ortega, 2012; Kubiszewski, Fontaine, Potard \& Auzoult, 2015) have looked specifically at the overlapping and similarities and/or differences between these two forms of intimidation.

Research has tackled the subject of cyberbullying mainly in adolescents, in other words, in secondary school students (Sentürk \& Bayat, 2016; Shin, Braithwaite \& Ahmed, 2016), but has recently even considered it among university students (Bauman \& Baldasare, 2015; Whittaker \& Kowalski, 2015). However, studies into cyberbullying at younger ages in children at primary school are scarce and clearly insufficient (Machimbarrena \& Garaigordobil, 2017; Fernández, Félix \& Ruiz, 2015). The literature leaves many unanswered questions in this age group.

Cyberbullying is an incipient reality for ten-year-old boys and girls. International studies have demonstrated that the digital environments which foster cyberbullying are primarily social networks and online chat groups, but also include email and mobile messaging (Notar, Padgett \& Roden, 2013). These are areas that children of this age do not normally frequent. The report by Net Children Go Mobile found that when they are seven, children start using the internet for games and entertainment but not for actual communication (Garmendia, Jiménez, Casado \& Mascheroni, 2016) which is where practices of intimidation and aggression can surface. The use of digital technologies for communicative and relational purposes is characteristic of older children. The report underlined that $15 \%$ of nine-yearold boys and girls had a profile in a social network, while this percentage rose to $83 \%$ among adolescents. In fact, in social networks such as Facebook the average age for creating a profile is around thirteen.

On the other hand, the study of the profiles involved in bullying have always focused on psychosocial variables. Studies such as that by Muller, Skues \& Wise (2017) approach attachment, the locus of control and coping styles as the psychological variables involved. Recent studies (Chan \& Wong, 2019) shows multivariate findings reveal that, to some extent, male and female adolescents shared a similar set of psychosocial risk factors of bullying perpetration, especially in the perpetration of traditional school 
bullying. The study by Kubiszewski, et al., (2015) incorporated psychosocial variables such as social disintegration. However, there have been very few studies which have looked at school variables associated to the children who suffer bullying and cyberbullying (Ortega-Barón, Buelga \& Cava, 2016). Others have studied how bullying affects the school climate and relate intimidation to the generation in victims of the feeling of not belonging at school (Glew, Fan, Katon \& Rivara, 2008). Other studies have focused on worse academic results in the victims (Mishna, Cook, Gadalla, Daciuk \& Solomon, 2010).

Finally, studies that have disaggregated data by gender and interpreted bullying and cyberbullying practices in terms of gender have not been conclusive (Mishna, Khoury-Kassabri, Gadalla \& Daciuk, 2012). Some studies have not shown significant gender differences between aggressors or victims (Hinduja \& Patchin, 2008), others have found that cyberbullying and traditional bullying are related to boys, not to girls (Erdur-Baker, 2009). Studies such as the one by Navarro, Yubero \& Larrañaga (2016) highlight the gender bias in the interpretations which have been made of the results. Essentially, the results have been read along basic gender lines whereby boys inflict harm more physically while girls do so more indirectly. However, research has shown that direct and indirect aggression strategies are common to both boys and girls. Studies have found that girls suffer more from cyberbullying than boys, but girls are also involved in cyberbullying practices (Giménez, Hunter, Durkin, Arnaiz, \& Maquilón, 2015).

The study of Mishna et al. (2018) uses a feminist lens to explore gendered and sexualized bullying and cyberbullying among children and youth. The findings indicate that while boys' roles and behaviors were frequently made invisible, girls were typically spotlighted, blamed, and criticized. Gendered and sexualized bullying and cyberbullying were found to be part of a socialization process wherein girls come to expect gender-based aggression, violence, and inequality in their lives. This study argues that "girls' victimization occurs because they belong to a gendered group that is systematically subordinated. When girls are encouraged to view their victimization as normal, trivial, their fault" (Mishna et al., 2018, p. 17). 
The objectives of this study are to:

1. Gauge the prevalence of bullying and cyberbullying in Spanish school-children in their fourth year of primary education using a representative population sample and from a gender perspective.

2. Identify groups of victims according to the forms of intimidation (bullying and/or cyberbullying) and intensity of the victimization, detecting profiles of multiple victimization.

3. Find out whether there are significant differences in gender in the groups of victims.

4. Locate school variables associated to the most vulnerable profile, characterizing this from a gender perspective.

\section{Material and Methods}

We conducted a secondary analysis from a data base of fourth-year pupils from the TIMSS 2015 study (Trends in International Mathematics and Science Study). The secondary studies such as the one we are presenting take certain study variables which were designed for other purposes. Thus, while the main objective of the TIMMS study promoted by the IEA (International Association for the Evaluation of Educational Achievement) is to examine academic achievement in maths and sciences, it also gathers extensive information about contextual factors affecting learning, including indicators on bullying and cyberbullying.

\section{Participants}

This study used the data from the Spanish sample of fourth-year primary pupils who completed the questionnaire. A total of 4756 children were involved (48.8\% girls and 51.2\% boys) with a mean age of 10 years $(\mathrm{M}=$ $10.18, \mathrm{SD}=.592$ ) from 179 schools. Of these, $77.5 \%$ had their own tablet or computer at home (49\% girls and 51\% boys); $79.7 \%$ had an internet connection at home (48.8\% girls and $51.2 \%$ boys); and $74.5 \%$ had their own mobile (50.4\% girls and $49.6 \%$ boys). 


\section{Instruments}

The context questionnaires for students included questions on different aspects of life at school. The contextual variables included some indexes available in the database of the TIMSS 2015. Details on the construction of these indexes, and the items used, can be consulted in the technical report produced for this purpose (Hooper, 2016; Martin et al. 2016).

The following measures were considered for this study:

- student gen/sex variable (ASBG01), which was question G1 in the questionnaire: 'Are you a girl or a boy?'

- school absenteeism variable (ASBG08), had four response options to question G8: 'About how often are you absent from school?' 'Once a week or more', 'Once every two weeks', 'Once a month', 'Never or almost never'.

- sense of belonging at school/idx variable (ASDGSSB). This refers to how students feel about their school and their relationship with the school community. This index comes from the seven response items to question G11 in the questionnaire: 'What do you think about your school? Tell how much you agree with these statements.' The items include: 'I feel like I belong at this school', 'I am proud to go to this school', or 'I feel safe when I am at school'. The measurement scale ranges from 1, 'Agree a lot' to 4='Disagree a lot'. The index has three modalities: 'high feeling of belonging', 'feeling of belonging at school' and 'low feeling of belonging at school'.

- confidence of the student in maths/idx variable (ASDGSCM). This index comes from 9 response items to question MS3 in the questionnaire: How much do you agree with these statements about mathematics? Items include: 'I usually do well in mathematics', 'Mathematics makes me nervous', 'I learn things quickly in mathematics'. The measurement scale ranges from 1='Agree a lot' to 4='disagree a lot'. The constructed index has three modalities: 'Very confident in maths', 'Confident in maths', 'Not confident in maths'. 
- confidence of the student in science/idx variable (ASDGSCS). This index comes from 7 response items to question MS6 in the questionnaire: How much do you agree with these statements about science? Items include: 'Science makes me confused', 'Science is harder for me than any other subject', or 'I am just not good at science'. The scale ranges from 1='Agree a lot' to 4='Disagree a lot'. The index has three modalities: "Very confident in science', 'Confident in science', 'Not confident in science'.

- bullying and cyberbullying/idx variable (ASDGSB). This index measures victimization and is constructed from 8 response items to question G12: During this school year, how often have other students from your school done any of the following things to you (including through texting or the Internet)? Items include 'Shared embarrassing information about me', 'Hit or hurt me (e.g., shoving, hitting, kicking)'. The scale ranges from 1='At least once a week' to 4='Never'. The index has three modalities: 'Never or hardly ever', 'Monthly' and 'Weekly'.

\section{Analysis and results}

We conducted descriptive analyses to assess the structure and distribution of the main variables involved and drew up contingency tables to establish differences in the prevalence of bullying and cyberbullying according to student gender. We also performed a cluster analysis to identify groups of students who suffered bullying and cyberbullying, determining the extent to which these two forms of intimidation overlap and concurred with different degrees of intensity in each profile. We used an ANOVA to gauge whether there were significant differences between these profiles. Finally, the multiple correspondence analysis allowed us to associate variables characterizing the most vulnerable group of students according to gender. We analysed the data using version 24 of the SPSS statistical package. 


\section{Prevalence of bullying and cyberbullying in Spanish primary school children.}

Of the total sample, 2839 primary school pupils had never suffered intimidatory practices, while 1121 suffered intimidatory practices each month and 699 were harassed on a weekly basis. The prevalence of bullying and cyberbullying among these pupils was $38.3 \%$. Amongst boys it was $23.24 \%$ and in girls $15.16 \%$. These were significant differences (Contingency coefficient .095, $\mathrm{p}=.000$ ).

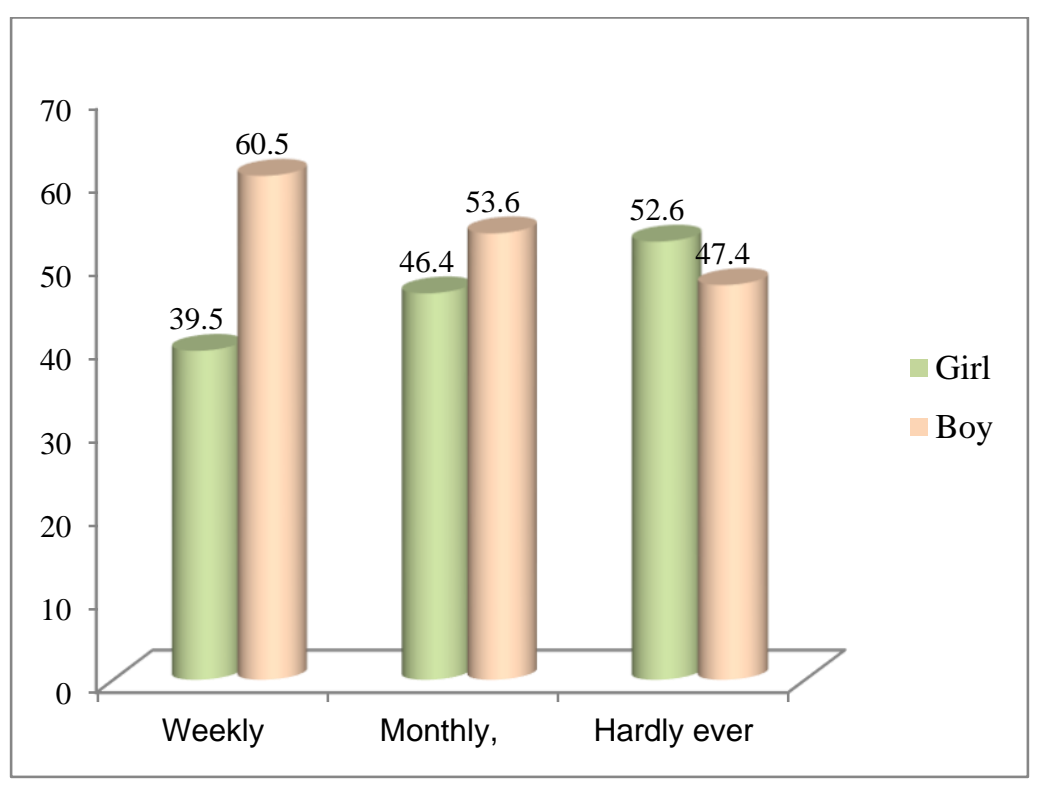

Figure 1. Victimization of primary school pupils according to gender 


\section{Groups of victims and most vulnerable profile in primary education in Spain according to gender.}

The cluster analysis revealed five different profiles. One group of students who did not suffer bullying (Group 2 with 2552 students), another group who were victims of severe school bullying (Group 1 with 499 students), one with victims of moderate bullying and cyberbullying (Group 3 with 342 students), victims of severe bullying and cyberbullying (Group 4 with 315 students) and incipient victims (moderate school bullying) (Group 5 with 796 students). The overlapping between forms of traditional bullying and cyberbullying occurred in two groups (3 and 4). The prevalence of multiple victimization was $14.52 \%$ (654 students).

Group 1 with victims of severe school bullying had been made fun of and called names, they had been left out of games and activities, lies had been spread about them, they had been robbed and they had been hit or hurt on a frequent basis. Group 5 of students were victims of moderate school bullying who had not experienced behaviours such as the spreading of lies about them, being robbed or continuous isolation, although they had at some time been hit or hurt. Groups 3 and 4 were characterized by suffering bullying and cyberbullying but with differing levels of intimidation intensity. Hence, Group 4 frequently suffered severe bullying and cyberbullying, being hit and having information shared about them, in addition to being made fun of and robbed. All forms of intimidatory practices coincided in this group. Group 3 also suffered all intimidation behaviours, but some to a lesser degree as a form of pressure to make them do things they did not want to, be left out of games or have things stolen. The differences between the groups were significant as reflected in table 2 . 
Table 2

Sample split into five clusters and the exploratory ANOVA

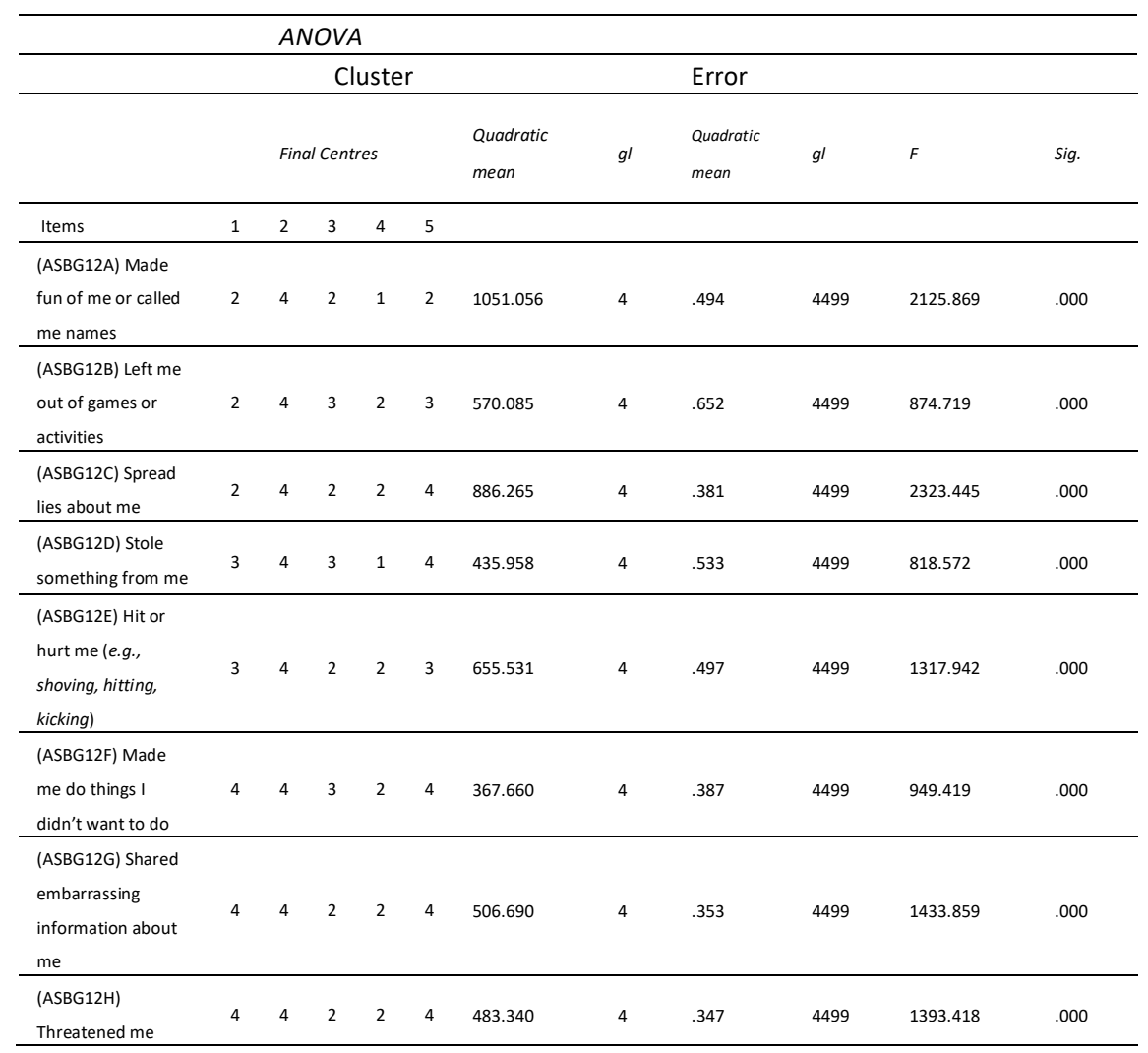


Jiménez-Multiple Victimization: Bullying \& Cyberbullying 180

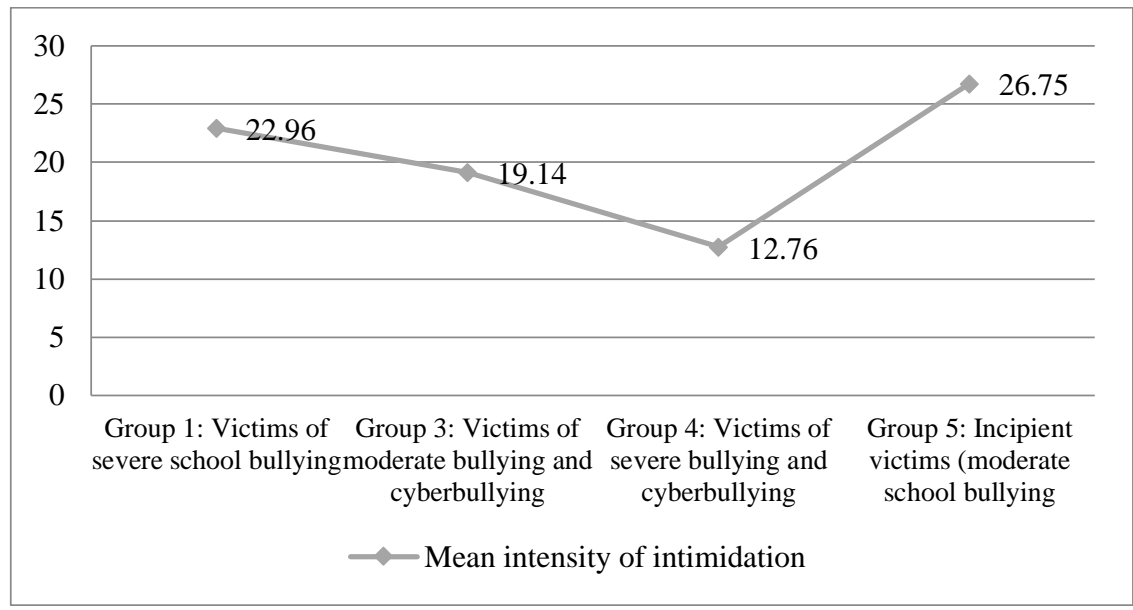

Figure 2. Intensity of intimidation in the different groups

There were significant differences among the four groups in terms of the intensity of the intimidation suffered $(\mathrm{F}=8472.347, \mathrm{gl} .=4, \mathrm{p}=.000)$. Group 4 was the most vulnerable, with victims of severe bullying and cyberbullying (Mean=12.76. $\mathrm{SD}=3.038)$. This group consisted of 315 students $(42.5 \%$ girls and $57.5 \%$ boys), compared to the group of incipient victims (who received moderate harassment), and which was the least vulnerable of the vulnerable groups $($ Mean= 26.75, $\mathrm{SD}=1.946)$.

\section{Gender differences between victims of bullying and cyberbullying in Spanish primary school children}

The results showed that in primary education boys suffered more bullying than girls. In terms of traditional school bullying, the percentage of girls in this group was slightly higher than that of boys (50.7\% versus $49.3 \%)$. However, the percentage of boys was higher than that for girls in the rest of the identified groups of victims. The difference was notable in Group 3 of victims of moderate bullying and cyberbullying, where boys accounted for $64.6 \%$ as opposed to $35.4 \%$ for girls. In the group of incipient victims, 
percentages were similar between boys and girls (52\% and 48\%, respectively).

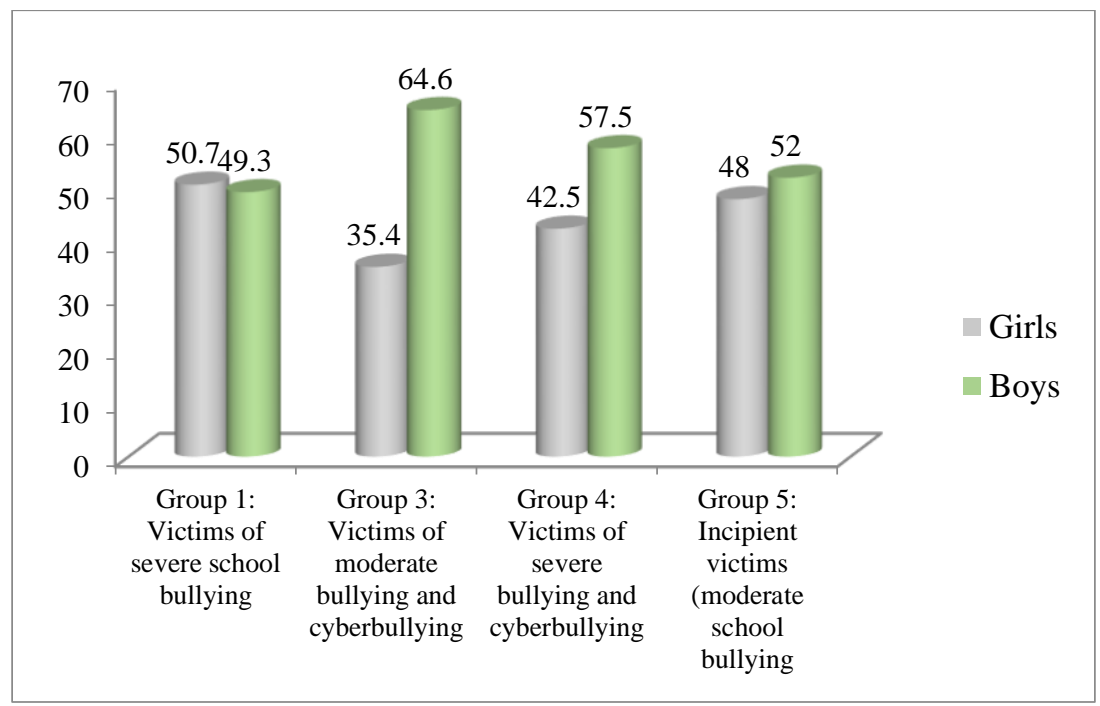

Figure 3. Groups of victims according to gender

The differences observed between boys and girls in the groups of victims were significant (Contingency coefficient, .099, $\mathrm{p}=.000$ ).

\section{School variables associated to the profile of most vulnerable students according to gender.}

The most vulnerable profile consisted of 315 students (134 girls and 181 boys). The school variables selected were oriented towards educational inclusion (school absenteeism and feeling of belonging at school) and predisposition towards STEM subjects (confidence in science and maths).

The results showed that the students in the most vulnerable group of victims did not usually present a high level of school absenteeism (61.3\% 
never missed or hardly ever missed school), while $19.7 \%$ missed school once a week or more and, of these, $65.7 \%$ were boys. As for the feeling of belonging at school, $48.9 \%$ showed a high feeling of belonging, only $15.7 \%$ showed a low feeling, and, of these, $63.3 \%$ were boys.

As for confidence in STEM subjects, we observed that $50.2 \%$ of the group of primary students who suffered severe bullying and cyberbullying did not present confidence in either maths or science $(49.7 \%)$. Boys showed least confidence $(59.5 \%$ of boys did not show confidence in science and $57.8 \%$ did not show confidence in maths).

The multiple correspondence analysis produced a model with two dimensions which explained $53.3 \%$ of the inertia. Dimension 1 (28.8\% of inertia) was defined by confidence towards STEM subjects and dimensions 2 (24.4\% of inertia) was determined by gender, feeling of belonging at school and school absenteeism.

Figure 4 shows two patterns of association differentiated and associated to gender. Girls who suffered severe bullying and cyberbullying were characterized by a high feeling of belonging at school, low school absenteeism (never or hardly ever missed school), showed confidence in maths but did not show confidence in science. Boys who suffered severe bullying and cyberbullying had a lower feeling of belonging at school, higher school absenteeism (missed school once a week), showed confidence in science, but not in maths. 
Table 3.

School variables of the most vulnerable groups according to gender

\begin{tabular}{|c|c|c|c|c|c|}
\hline & School variables & Modalities & $\%$ Girl & $\%$ Boy & $\begin{array}{l}\% \text { Tot } \\
\text { al }\end{array}$ \\
\hline \multirow{7}{*}{ 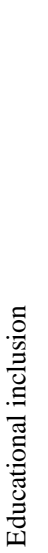 } & \multirow{4}{*}{$\begin{array}{l}\text { School } \\
\text { absenteeism }\end{array}$} & Once a week or more & 44.3 & 65.7 & 19.7 \\
\hline & & Once every two weeks & 37.9 & 62.1 & 9.4 \\
\hline & & Once a month & 26.7 & 73.3 & 9.7 \\
\hline & & Never or hardly ever & 45.3 & 54.7 & 61.3 \\
\hline & \multirow{3}{*}{$\begin{array}{l}\text { Feeling of } \\
\text { belonging at } \\
\text { school }\end{array}$} & High feeling of belonging & 49 & 51 & 48.9 \\
\hline & & Feeling of belonging & 35.1 & 64.9 & 35.5 \\
\hline & & Low feeling of belonging & 36.7 & 63.3 & 15.7 \\
\hline \multirow{6}{*}{ 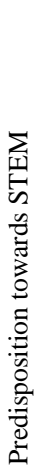 } & \multirow{3}{*}{$\begin{array}{l}\text { Confidence in } \\
\text { maths }\end{array}$} & Very confident in maths & 42.6 & 57.4 & 15.3 \\
\hline & & Confident in maths & 41.5 & 58.5 & 34.5 \\
\hline & & Not confident in maths & 42.2 & 57.8 & 50.2 \\
\hline & \multirow{3}{*}{$\begin{array}{l}\text { Confidence in } \\
\text { science }\end{array}$} & Very confident in science & 46.8 & 53.2 & 15.8 \\
\hline & & Confident in science & 41.7 & 58.3 & 34.6 \\
\hline & & Not confident in science & 40.5 & 59.5 & 49.7 \\
\hline
\end{tabular}


Jiménez-Multiple Victimization: Bullying \& Cyberbullying 184

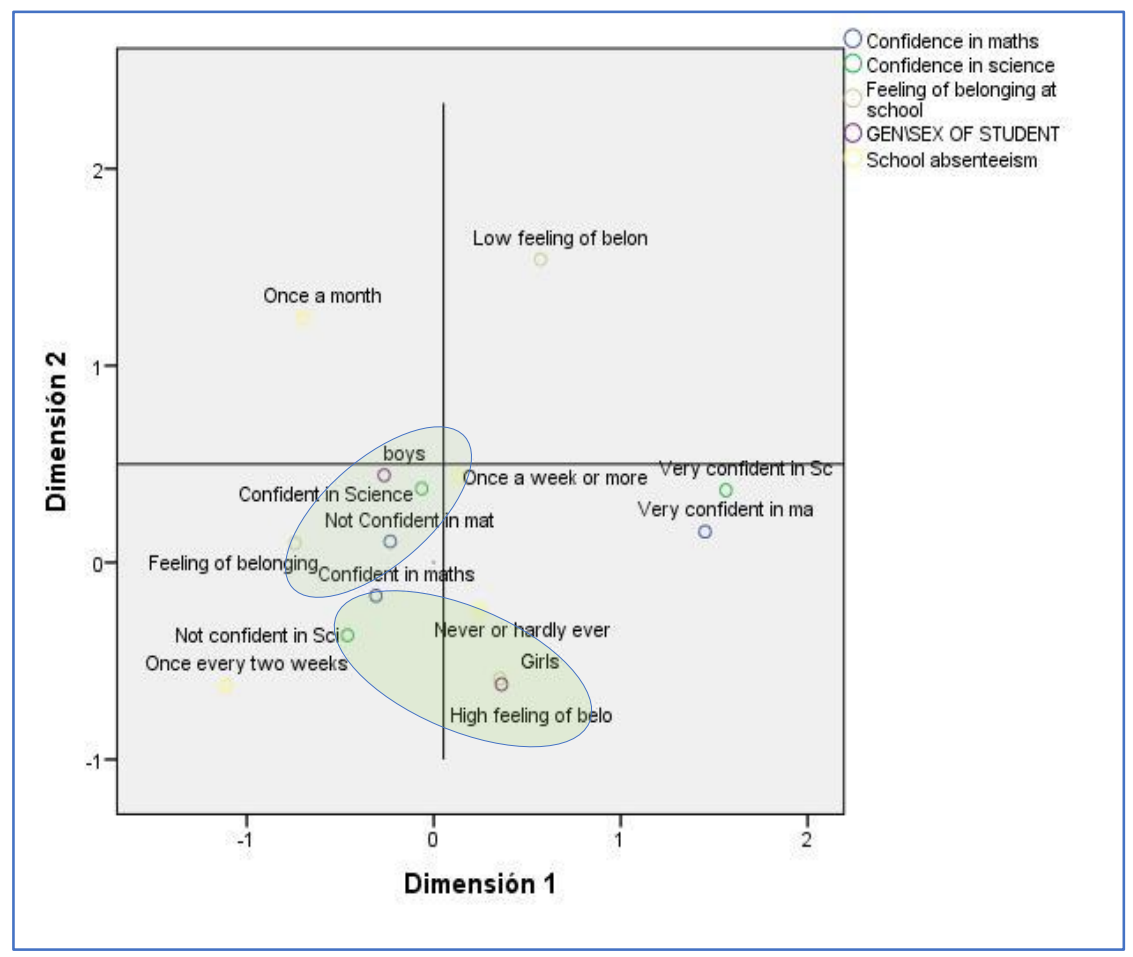

Figure 4. Perceptual map of associated school variables

\section{Discussion and conclusions}

The results showed a prevalence of $38.3 \%$ of bullying and cyberbullying in primary education in Spain, with this prevalence being greater amongst boys than girls. The prevalence of multiple victimization was $14.52 \%$ in ten-yearold children (where it was also higher among boys). It is difficult to compare this study with others in terms of general prevalence because either their data came from secondary school students (Calmaestra et al., 2016), or was obtained from primary school samples which were small, local and/or regional (González, Prendes \& Espinosa, 2016) or they are now out of date 
(Garaigordobil, 2011). The figure for prevalence is always going to be very dynamic and depend on a variety of factors such as the penetration or usage of technologies, hence it is subject to constant evolution and change.

Measurements of bullying and cyberbullying used in research may be giving inconsistent results both in prevalence and in gender differences (Slonje \& Smith, 2008). We know that measurements of bullying and cyberbullying are not gender sensitive because they do not incorporate what is understood as harassing behaviour by each gender (Navarro, 2016). In adolescent students, studies (Giménez, et al., 2015; Macaulay, Boulton \& Betts 2018) have shown that girls are victims of cyberbullying to a greater degree; in contrast, boys are involved as victims and aggressors to a greater extent. Our study placed primary boys in a clear multiple victimization profile compared to girls. However, in traditional school bullying, in percentage terms, girls exceed boys as victims. This finding coincides with other studies (Del Rey, et al., 2012). Studies that show girls being victims more than boys are with samples of adolescents where online intimidatory practices are clearly demarcated and close to intimate partner violence and gender violence (Donoso, Rubio, Velasco \& Vila, 2014). The findings of other very current studies in adolescents (Chan \& Wong, 2019) indicate that the perpetration of traditional school bullying and cyberbullying behaviors are positively correlated, and male adolescents reported higher levels of bullying perpetration than female adolescents. Delgado y Escortell (2018) indicate that girls are significantly more victimized than boys and score higher on five victimizing behaviors. The objective of this study is to analyze the differences in cyberbullying (victims, bullies, and bystanders) according to the sex and grade of the participants. The sample consisted of students of primary education.

In terms of age, the practice of digital bullying has been well identified and documented in students aged 14 to 18 , but not in children aged 9 to 12 who are just initiating communications and relations in digital surroundings. That is why research needs to delimit intimidatory practices via digital technologies in a more age sensitive manner. To this, we need to add the level of awareness of cyberbullying related behaviours (Akbaba, Peker, Eroğlu \& Yaman, 2015). 
The results from this study delimit two profiles in which traditional bullying and cyberbullying overlap in victims. This highlights the existence of multiple victimization at an early age. Controversy in current research about measurements of school bullying and cyberbullying stems from studies which adopt a different approach to construct measurement (Hinduja \& Patchin, 2013). For Erdur-Baker (2010), cyberbullying and traditional intimidation share some points in common, but cyberbullying has its own identity. Notar, et al. (2013) point to the overlapping between traditional bullying and cyberbullying, being forms of intimidation which coincide and overlap. The study by Modecki, Minchin, Harbaugh, Guerra \& Runions (2014) highlighted that traditional bullying and cyberbullying correlate closely, showing that those involved in these practices participate in a multiple aggression. In contrast, the study by Kubiszewski et al. (2015), showed that students involved in cyberbullying and students involved in school bullying belonged to different groups. This analysis inferred that cyberbullying was not an extension of school bullying. As Ortega et al. (2012) states, these controversies underline the complexity of the study phenomena. It may be an error to apply the same unit of measurement to categories of traditional bullying and cyberbullying especially at ages at which they are starting to use digital technologies, particularly when research has still not established the factorial structure of the construct of cyberbullying Kowalski, Giumetti, Schroeder, \& Lattanner (2014) argue that more work is needed to gain a better understanding of the dimensional structure of cyberbullying.

Although studies have found that aggressors make victims feel that they do not belong (Glew, et al., 2008), no previous studies have explored these differences in terms of gender. We found that boy victims of multiple victimization were more exposed to school exclusion, because of having a lower feeling of belonging at school and having a higher level of absenteeism. In girl victims of multiple harassment, there was no school absenteeism and the feeling of belonging at school was high. These findings would seem to indicate that girls have more assertive coping strategies or may be more inclined to ask for help; some victims may even be unaffected in line with the results of Ortega et al. (2012). 
The impact of bullying on results at school has been studied (Mishna et al., 2010), but this is not the case with confidence in STEM subjects amongst the most intimidated students. This prevents educational action being taken, despite these subjects being crucial from a gender perspective in terms of a future professional career. Neglect of these areas, particularly in this group of students, can be added to other factors leaving them in a situation of complete academic vulnerability. To this can be added school absenteeism, which is much more prevalent amongst boy victims, and the risks of entering a digital world which is novel from a relational point of view. Marín, Hoyos \& Sierra (2019) show that the risk and protective factors are related to the use of the Internet and information and communication technologies, family, social, psychological and individual aspects.

To conclude, we believe that studies published thus far on bullying and cyberbullying fall short of providing a response to this social and educational challenge, due to the wide range of measurements and their lack of sensitivity to gender and age. Research is needed with alternative research methodologies to allow us to build adequate educational knowledge for this reality from the perspective of the student involved. In this sense, it is clear that the field of study needs to be widened together with recognition that inter-peer aggression must be analysed from an ecological perspective (De la Caba \& López, 2013). The incorporation of academic variables to the study will also provide a greater number of keys for designing intervention programmes that are more likely to be satisfactory.

Some interventions are helping to improve this reality. Some of the programs that are being carried out in our schools, and that specifically address the different forms of harassment are among others Cyberprogram 2.0 (Garaigordobil y Martínez-Valderrey, 2014) and ConRed Program (Del Rey, Casas y Ortega, 2012).

The study (Garaigordobil y Martínez-Valderrey, 2014) was to assess experimentally the effects of an antibullying program (Cyberprogram 2.0) on behaviors of victimization due to «face-to-face» bullying and on diverse social behaviors. The intervention significantly decreased some negative social behaviors to a greater extent in females, although in the remaining variables, the change was similar both sexes. 
The ConRed Program (Del Rey, Casas y Ortega, 2012) is based on the theory of normative social behavior and aims to reduce problems such as cyber-bullying and addiction to the Internet and refocus the misadjusted perception of information control in the social networks in order to promote their use in a more beneficial way. The ConRed Program has been evaluated using a quasi-experimental methodology. According to the authors, the study shows evidence of the program's validity, and show that by working and collaborating with the whole educational community it is possible to improve the quality of the life of adolescents.

The findings of this study may have important implications for practice in regard to minimizing, if not entirely preventing, through the joint efforts of the school the propensity of scholars to engage in the perpetration of bullying behaviors.

\section{References}

Akbaba, S., Peker, A., Eroğlu, Y., \& Yaman, E. (2015). Cross-gender equivalence of cyber bullying and victimization. Participatory Educational Research, 2(2), 59-69. doi:10.17275/per.15.15.2.2

Bauman, S., \& Baldasare, A. (2015). Cyber aggression among college students: Demographic differences, predictors of distress, and the role of the university. Journal of College Student Development, 56(4), 317330. doi:10.1353/csd.2015.0039

Calmaestra, J. Escorial, A., García, P., del Moral, C., Perazzo, C., \& Ubrich, T. (2016). Yo a eso no juego. Bullying y ciberbullying en la infancia. España: Save the Children. Retrieved from https://www.savethechildren.es/sites/default/files/imce/docs/yo_a_es o_no_juego.pdf

Chan, H. Ch. \& Wong, D. (2019). Traditional school bullying and cyberbullying perpetration: Examining the psychosocial characteristics of Hong Kong male and female adolescents. Youth \& Society, 5I(1), 3-29. doi:10.1177/0044118X16658053

De La Caba, M. Á., \& López, R. (2013). La agresión entre iguales en la era digital: Estrategias de afrontamiento de los estudiantes del último ciclo 
de primaria y del primero de secundaria. Revista de Educación, 362, 247-272. doi:10.4438/1988-592X-RE-2011-362-160

Del Rey, R., Casas, J. \& Ortega-Ruiz, R. (2012). The ConRed Program, an Evidence-based Practice. Comunicar, 39, 129-138. doi:10.3916/C392012-03-03

Del Rey, R., Elipe, P., \& Ortega-Ruiz, R. (2012). Bullying and cyberbullying: Overlapping and predictive value of the co-occurrence. Psicothema, 24(4), 608-613. doi:10.3916/c39-2012-03-03

Delgado, B. \& Escortell, R. (2018). Sex and grade differences in cyberbullying of spanish students of 5th and 6th grade of Primary Education. Annals of Psychology, 34(3), 472-481. doi:10.6018/analesps.34.3.283871

Donoso, T., Rubio, M. J., Velasco, A. y Vilà, R. (2014). Ciberacoso en función del género: Propuestas de análisis. Ponencia presentada a $V$ Congreso Universitario Internacional Investigación y Género, Sevilla.

Erdur-Baker, O. (2009). Cyberbullying and its correlation to traditional bullying, gender and frequent and risky usage of internet-mediated communication tools. New Media \& Society, 12(1), 109-125. doi:10.1177/1461444809341260

Fernández, C. M. G, Félix, E. M. R, \& Ruiz, R. O. (2015). Factores explicativos del hostigamiento cara a cara y el ciberacoso en una muestra de alumnos de primaria. Psicothema, 27(4), 347-353.doi: 10.7334/psicothema2015.35

Garaigordobil, M. (2011). Prevalencia y consecuencias del cyberbullying: Una revisión. International Journal of Psychology and Psychological Therapy, 11(2), 233-254.

Garaigordobil, M., Martínez, V., \& Machimbarrena, J. M. (2014). Intervención en el bullying y cyberbullying: Evaluación del caso Martín. Revista de Psicología Clínica con Niños y Adolescentes, 4(1), 25-32. Retrieved from:

https://dialnet.unirioja.es/descarga/articulo/5789316.pdf

Garmendia, M. Jiménez, E., Casado, M.A., \& Mascheroni, G. (2016). Net Children Go Mobile: Riesgos y oportunidades en internet y el uso de 
dispositivos móviles entre menores españoles (2010-2015). Madrid: Red.es, Universidad del País Vasco and Euskal Herriko Unibertsitatea. Giménez, A. M., Hunter, S. C., Durkin, K., Arnaiz, P., \& Maquilón, J.J. (2015). The emotional impact of cyberbullying: Differences in perceptions and experiences as a function of role. Computers \& Education, 82, 228-235. doi:10.1016/j.compedu.2014.11.013 Glew, G. M., Fan, M., Katon, W., \& Rivara, F. P. (2008). Bullying and school safety. The Journal of Pediatrics, 152(1), 123-128. doi:10.1016/j.jpeds.2007.05.045

González, V., Prendes, M ${ }^{a}$ P., \& Espinosa, J. A. (2016). Víctimas de ciberacoso: Estudio descriptivo en la Región de Murcia. In R. RoigVila (Coord.), Tecnología, innovación e investigación en los procesos de enseñanza (pp. 1661-1669). Barcelona: Octaedro.

Hinduja, S., \& Patchin, J. W. (2008). Cyberbullying: An exploratory analysis of factors related to offending and victimization. Deviant Behavior, 29(2), 1-29.

Hinduja, S., \& Patchin, J. W. (2013). Social influences on cyberbullying behaviors among middle and high school students. Journal of Youth and Adolescence, 42(5), 711-722. doi:10.1007/s10964-012-9902-4

Hooper, M. (2016). Developing the TIMSS 2015 context questionnaires. In M. O. Martin, I. V. S. Mullis, \& M. Hooper (Eds,). Methods and Procedures in TIMSS 2015 (pp. 2.1-2.8). Retrieved from: http://timss.bc.edu/publications/timss/2015-methods/chapter-2.html

Kowalski, R. M., Giumetti, G. W., Schroeder, A. N., \& Lattanner, M. R. (2014). Bullying in the digital age: A critical review and meta-analysis of cyberbullying research among youth. Psychological Bulletin, 140(4), 1073-1137. doi:10.10 37/a0035618

Kubiszewski, V., Fontaine, R., Potard, C., \& Auzoult, L. (2015). Does cyberbullying overlap with school bullying when taking modality of involvement into account? Computers in Human Behavior, 43, 49-57. doi:10.1016/j.chb.2014.10.049

Macaulay, P. J., Boulton, M. J., \& Betts, L. R. (2018). Comparison of the positive responses of primitive adolescents to cyberbullying and traditional bullying: the impact of gravity and gender. Journal of 
Technology in Behavioral Science, 1-9. doi:10.1007/s41347-0180082-2

Machimbarrena, J. M., \& Garaigordobil, M. (2017). Bullying/cyberbullying en quinto y sexto curso de primaria: Diferencias entre centros públicos y privados. Anales de Psicología, 33(2), 319-326. doi: 10.6018/analesps.33.2.249381

Maquilón, J. J., Giménez, A. M., Hernández, F., \& García, A. (2011). La victimización en las dinámicas de ciberbullying en centros educativos de la región de Murcia. International Journal of Developmental and Educational Psychology, 2(1), 265-276. Retrieved from: http://www.redalyc.org/articulo.oa?id=349832329026

Marín, A. F., Hoyos, O. L. \& Sierra, A. (2019). Risks and protective factors related to cyberbullying among adolescents: A systematic review. Psychologist Papers, Online advance publication. doi:10.23923/pap.psicol2019.2899

Martin, M. O., Mullis, I. V. S., Hooper, M., Yin. L., Foy, P., \& Palazzo, L. (2016). Creating and Interpreting the TIMSS 2015 Context Questionnaire Scales. In M.O. Martin, I.V.S. Mullis, \& M. Hooper (Eds.). Methods and Procedures in TIMSS 2015 (pp. 15.1-15.312). Retrieved from: http://timss.bc.edu/publications/timss/2015methods/chapter-15.html

Mishna, F., Schwan, K. J., Birze, A., Van Wert, M., Lacombe-Duncan, A., McInroy, L., \& Attar-Schwartz, S. (2018). Sexist and sexualized intimidation and cyberbullying: highlight girls and make children invisible. Youth and Society, 1-24. doi: 10.1177/0044118X18757150

Mishna, F., Cook, C., Gadalla, T., Daciuk, J., \& Solomon, S. (2010). Cyber bullying behaviours among middle and high school students. American Journal of Orthopsychiatry, 80, 362-374. doi:10.1111/j.1939-0025.2010.01040.x

Modecki, K. L., Minchin, J., Harbaugh, A. G., Guerra, N. G., \& Runions, K. C. (2014). Bullying prevalence across contexts: A meta-analysis measuring cyber and traditional bullying. Journal of Adolescent Health, 55(5), 602-611. doi:10.1016/j.jadohealth.2014.06.007

Muller, R. D., Skues, J. L., \& Wise, L. Z. (2017). Cyberbullying in australian primary schools: How victims differ in attachment, locus of control, 
self-esteem, and coping styles compared to non-victims. Journal of Psychologists and Counsellors in Schools, 27(1), 85-104. doi:10.1017/jgc. 2016.5

Navarro, R. (2016). Gender issues and cyberbullying in children and adolescents: From Gender Differences to Gender Identity Measures. In R. Navarro., S. Yubero, \& E. Larrañaga (Eds,). Cyberbullying across the globe gender, family, and mental health (pp.35-64). Suiza: Springer.

Navarro, R., Yubero, S., \& Larrañaga, E. (2016). Cyberbullying across the globe gender, family, and mental health. Suiza: Springer.

Notar, C. E., Padgett, S., \& Roden, J. (2013). Cyberbullying: A review of the literature. Journal of Educational Research, 1(1), 1-9. doi:10.13189/ujer.2013.010101

Ockerman, M. S., Kramer, C., \& Bruno, M. (2014). From the school yard to cyber space: A pilot study of bullying behaviors among middle school students. Research in Middle Level Education Online, 37(6), 1-18. doi:10.1080/19404476.2014.11462109

Olweus, D. (2013). School bullying: development and some important challenges. Annual Review of Clinical Psychology, 9, 751-780. doi:10.1146/annurev-clinpsy-050212-185516.

Ortega, R., Elipe, P., Mora-Merchán, J. A., Genta, M. L., Brighi, A., Guarini, A., Smith, P. K., Thompson, F., \& Tippett, N. (2012). The emotional impact of bullying and cyberbullying on victims: A european crossnational study. Aggressive Behavior, 38(5), 342-356. doi:10.1002/ab.21440

Ortega-Barón, J., Buelga, S., \& Cava, M. J. (2016). The influence of school climate and family climate among adolescent victims of cyberbullying. Comunicar, 24(46), 57-65. doi:10.3916/C46-2016-06

Sentürk, S., \& Bayat, S. (2016). Habits of internet use and cyber harassment related opinions of high school students. Universal Journal of Educational Research, 4(5), 1103-1110. doi:10.13189/ujer.2016.040520

Shin, V., Braithwaite, A., \& Ahmed, E. (2015). From traditional face- to-face bullying to cyberbullying: Who crosses over? RegNet Research Paper, 75, 1-34. doi:10.2139/ssrn.2601197 
Slonje, R., \& Smith, P. K. (2008). Cyberbullying: Another main type of bullying? Personality and social sciences. Scandinavian Journal of Psychology, 49(2), 147-154. doi:10.1111/j.1467-9450.2007.00611.x

Vivolo-Kantor, A. M., Martell, B. N., Holland, K. M., \& Westby, R. (2014). A systematic review and content analysis of the measurement strategies of bullying and cyberbullying. Aggression and Violent Behavior, 19(4), 423-434. doi:10.1016/j.avb.2014.06.008

Whittaker, E., \& Kowalski, R. M. (2015). Cyberbullying through social networks. Journal of School Violence, 14(1), 1-29. doi:10.1089/cpb.2007.0008

Rocío Jiménez es Profesora en la Universidad de Sevilla, investigadora en el Grupo de Investigación: Diseños de Modelos Educativos HUM833

ORCID: http://orcid.org/0000-0003-1622-5805

Contact Address: Universidad de Sevilla. Facultad Ciencias de la Educación. Departamento Métodos de Investigación y Diagnóstico en Educación. C/ S. Fernando, 4, C.P. 41004- Sevilla, España.

Email: rjimenez@us.es 